arteriovenous malformation in a pregnant patient by MR imaging. J Comp Assist Tomogr 1985;9:171-3.

28 Modic MT, Hardy RW Jr, Weinstein MA, et al. Nuclear magnetic resonance of the spine: clinical potential and limitation. Neurosurgery 1984;15:583-92.

29 Modic MT, Masaryk T, Paushter D. Magnetic resonance imaging of the spine. Radiology Clin North America 1986;24:229-45.

30 Quencer RM, Sheldon JJ, Post MJD, et al. Magnetic resonance imaging of the chronically injured cervical spinal cord. AJNR 1986;7:457-64.

31 Rossi DR, Charney AS. Magnetic resonance imaging of the spine. Semin Neurol 1986;6:84-93.

32 Miller DH, McDonald WI, Blumhardt LD, et al. Magnetic resonance imaging in isolated noncompressive spinal cord syndromes. Ann Neurol 1987;22:714-23.

33 Kurtzke JF. Rating neurological impairment in multiple sclerosis: an expanded disability status scale (EDSS). Neurology 1983;33:1444-52.

34 Adams RD, Kubik CS. The morbid anatomy of the demyelinative diseases. Am J Med 1952;12:510-46.

35 Ikuta F, Zimmerman HM. Distribution of plaques in seventy autopsy cases of multiple sclerosis in the United States. Neurology 1976;26(Suppl):26-8.

36 Honig LS, Ramsay RE, Sheremata WA, Resillez M, Wong P, Sazant A. Magnetic resonance imaging (MRI), cognitive impairment, and the P300 event-related potential (ERP) in patients with multiple sclerosis. Neurology 1986;36(Suppl 1): 157 .

37 Runge VM, Clanton JA, Lukehart CM, Partain CL, James AE Jr. Paramagnetic agents for contrast-enhanced NMR imaging: a review. AJR 1983;141:1209-15.

38 Bydder GM, Brown J, Niendorf HP, Young IR. Enhancement of cervical intrasponal tumors in MR imaging with intravenous Gadolinium-DTPA. J Comp Assist Tomogr 1985;9:847-51.

39 Gonzalez-Scarano F, Grossman RI, Galetta S, Atlas SW, Silberberg DH. Multiple sclerosis disease activity correlates with gadolinium-enhanced magnetic resonance imaging. Ann Neurol 1987;21:300-6.

\title{
Early descriptions of cluster headache
}

Priority for description of cluster headache or periodic migrainous neuralgia is a source of polemic. Much depends upon the stringency of criteria applied. Hierons ${ }^{1}$ refers to Thomas Willis (1621-1675) who described a venerable matron who began to suffer every afternoon at 4 o'clock from recurring severe headache.

In 1747 Joannes Christoph Ulricus Oppermann published his little acknowledged Dissertatio Medica Inauguralis, entitled Hemicrania Horologica which may be the first account ${ }^{2}$ of the variant, chronic paroxysmal hemicrania, to which I will refer in a later piece.

Benjamin Hutchinson's description of "neuralgia spasmodica" is often cited as the original account of cluster headache: with attacks every 24 hours, but lasting for several hours. The nature of these attacks is dubious, and some were probably tic douloureux.

Romberg in his classic Manual ${ }^{3}$ records: painful sensations in the eye, confined to one side and excited by rays of light and visual effort ... The pupil is contracted. The eye generally weeps and becomes red. These symptoms occur in paroxysms, of a uniform and irregular character, and isolated or combined with facial neuralgia and hemicrania. Romberg's emphasis on the photophobia ${ }^{4}$ is incongruous with current concepts, but he was clearly observing a condition closely akin to cluster headache.

\section{References}

1 Hierons R. Willis's contribution to clinical medicine and neurology. J Neurol Sci 1967;4:1-6.

2 Oppermann, Joannes Christoph Ulricus. Dissertatio Medica Inauguralis. "Hemicrania Horologica" pro gradu doctoris, 1747.

3 Romberg MH. A manual of nervous diseases in man. trans: Sieveking. London Sydenham Society 1983;1:56.

4 Pearce JMS. The enigma of migrainous neuralgia. Physician India 1986;3:141-50. 